\title{
Effect of Ozone Gas on Degradation of Aflatoxin B1 and Aspergillus Flavus Fungal
}

\author{
El-Desouky TA ${ }^{1 *}$, Sharoba AMA², A I El-Desouky², El-Mansy HA² and Khayria Naguib ${ }^{1}$
}

${ }^{1}$ Food Toxicology and Contaminants Department, National Research Center, Dokki, Cairo, Egypt

${ }^{2}$ Food Science Department, Moshtohor Faculty of Agriculture, Banha University, Egypt

\begin{abstract}
Wheat (Triticum aestivum) is one of the most important agricultural crops. Requirements, wheat must be produced free of hazardous contaminants. However, previous investigations showed that wheat could be contaminated by aflatoxins above the limits that may be critical for health. In this study, use of the high oxidising power of ozone achieved degradation of aflatoxin $B_{1}$. Samples were subjected to ozonation at various ozone concentrations (20,40ppm) and exposure time $(5,10,15,20 \mathrm{~min})$. The reduction percentages of aflatoxin $\mathrm{B}_{1}$ in artificially contaminated wheat $10 \mu \mathrm{g} / \mathrm{kg}$ were 84.1 and $86.75 \%$ after exposures to 20 and 40 ppm ozone for 20min respectively, and 86.7 and $96.66 \%$ with 20 $\mu \mathrm{g} / \mathrm{kg}$ after exposures 20 and 40 ppm ozone for $20 \mathrm{~min}$, respectively. The percentage of inhibition zone from Aspergillus flavus was $46.4 \%$ to $87.8 \%$ after ozonation using concentration 20 ppm for 5 and 20 min respectively. While with 40 ppm ozone inhibition zone was $65.6 \%$ and $95.6 \%$ with 5 and 20 min respectively. Exposure of strain to 20 ppm ozone inhibition of product of AFB percentage of $40.94 \%, 52.5 \%, 59.32 \%$ and $60.4 \%$ for exposure time $5,10,15$ and 20 min, respectively. However, observed increase on inhibition of $A_{F} B_{1}$ with topping up ozone dose to 40 ppm attained $55.2 \%$, $64 \%, 74.5 \%$ and $77.2 \%$ with $5,10,15$ and 20 min exposure time respectively.
\end{abstract}

Keywords: Aflatoxin $\mathrm{B}_{1}$; Degradation; Ozone; Aspergillus flavus; Wheat

\section{Introduction}

Aflatoxins (AFs) are a group of highly carcinogenic mycotoxins produced primarily by the fungus Aspergillus flavus. Within the group of $A F s$, Aflatoxin $B_{1}\left(A_{1} B_{1}\right)$ is the most toxic, and it is known for its harmful effects on humans and animals. AFs contamination is a worldwide problem, especially in warmer climates, and the toxin can enter the food chain through contaminated food and feed products. They are considered an unavoidable food and feed contaminant [1].

$\mathrm{AFB}_{1}$ is the most potent of the four naturally occurring AFs and because of its remarkable hepatotoxicity and carcinogenicity, this feed contaminant has been the focus of considerable research since its discovery [2].

According to Cardwell et al. [3] AFs contamination of agricultural crops causes annual losses of more than $\$ 750$ million in Africa. Jolly et al. [4] also reveal that post-harvest losses of crops are greater than the improvements made in primary production. In the US, it was reported that income losses due to AFs contamination cost an average of more than US $\$ 100$ million per year to US producers [5]. Toxigenic fungi infect agricultural crops both in the field and in storage. Conditions favoring the development of mycotoxins in cereals before and after harvest are important to grain exporting countries concerned with marketing high-quality products. In post-harvest situations, crop spoilage, fungal growth, and mycotoxin formation result from the interaction of several factors in the storage environment [6-8]. These factors include: moisture, temperature, time, insect vectors, damage to the seed, oxygen levels, composition of substrate, fungal infection level, prevalence of toxigenic strains of fungi, and microbiological interactions. An understanding of the interactions involved would facilitate prediction and prevention of mycotoxin development, particularly in newly developed cereal cultivars. Aspergillus flavus and A. parasiticus, the most important.

A variety of chemical, physical, and biological treatments have been tested for their ability to reduce or eliminate the AFs in contaminated feeds and foods $[9,10]$. Ozonation, an oxidation method, has recently been developed for the detoxification of AFs in foods [11]. Ozone, or triatomic oxygen $\left(\mathrm{O}_{3}\right)$, is a powerful disinfectant and oxidising agent [12]. Ozone treatment of grain is generally applied in silos or vessels. Prior to ozone application, it is necessary to characterise the dynamics of ozone movement through the various grain types to optimise ozone generators for use on large commercial storage bins [13]. Ozone either completely degrades mycotoxins or causes chemical modifications, reduc ing their biological activity $[12,14,15]$. Ozone reacts across the 8 , 9 double bond of the furan ring of $\mathrm{AFB}_{1}$ through electrophilic attack, causing the formation of primary ozonides followed by rearrangement into monozonide derivatives such as aldehydes, ketones and organic acids [16]. There are many methods for the production of ozone, such as electrical discharge in oxygen, electrolysis of water, or thermal, photochemical or radiochemical methods. For industrial use ozone is generated mainly from pure oxygen or atmospheric oxygen in a corona discharge process $[12,15]$. In corona discharge, air or pure oxygen is fed into a unit that converts the oxygen to ozone using high voltage. The attractive aspect of ozone is that it decomposes rapidly (half-life of 20-50 $\mathrm{min}$ ) to molecular oxygen without leaving a residue [17]. Several research studies have been undertaken to evaluate the effects of ozone gas in reducing AFs levels in contaminated agricultural products. Maeba $\mathrm{H}$ et al. [18] reported that $\mathrm{AFB}_{1}$ and $\mathrm{AFG}_{1}$ were sensitive to ozone and easily degraded with $1.1 \mathrm{mg} / \mathrm{L}$ of ozone within $5 \mathrm{~min}$ at room temperature. On the other hand, $\mathrm{AFB}_{2}$ was resistant to ozone, requiring

*Corresponding author: El-Desouky, Food Toxicology and Contaminants Dept., National Research Center, Dokki, Cairo, Egypt, E-mail:mr_tarekhad@yahoo.com

Received January 29, 2012; Accepted February 27, 2012; Published February 29, 2012

Citation: El-Desouky TA, Sharoba AMA, El-Desouky AI, El-Mansy HA, Naguib K (2012) Effect of Ozone Gas on Degradation of Aflatoxin B1 and Aspergillus Flavus Fungal. J Environment Analytic Toxicol 2:128. doi:10.4172/2161-0525.1000128

Copyright: ( 2012 El-Desouky TA, et al. This is an open-access article distributed under the terms of the Creative Commons Attribution License, which permits unrestricted use, distribution, and reproduction in any medium, provided the original author and source are credited. 
50-60 min to degrade them completely with $34.3 \mathrm{mg} / 1$ of ozone. Inan et al. [19] used of ozone in the detoxification of $\mathrm{AFB}_{1}$ in red pepper. The process reduced the $\mathrm{AFB}_{1}$ content in flaked red pepper by as much as $80 \%$ after ozonation for $60 \mathrm{~min}$. Initial $\mathrm{AFB}_{1}$ level of $32 \mathrm{ppb}$, was reduced by as much as $93 \%$ after exposure to gaseous ozone for 60 minutes. Allen et al. [20] used gaseous ozone to inactivate fungi in barley grain. They found that at an ozonation rate of $0.01 \mathrm{mg} / \mathrm{g} / \mathrm{min} 39 \%$ of fungal spores were inactivated after $5 \mathrm{~min}$ of treatment. As the ozone rate increased, the level of spore inactivation increased; $78 \%$ inactivation at a rate of $0.07 \mathrm{mg} / \mathrm{g} / \mathrm{min}$ and a $96 \%$ inactivation at a rate of $0.16 \mathrm{mg} / \mathrm{g} / \mathrm{min}$. A rate of $0.98 \mathrm{mg} / \mathrm{g} / \mathrm{min}$ did not result in further inactivation. Wu et al. [21] reported that gaseous ozone was very effective in the inactivated of fungi associated with the wheat within $5 \mathrm{~min}$ of ozonationtion, $96.6 \%$ of the fungal spores were inactivated by applying $0.33 \mathrm{mg}$ of ozone $(\mathrm{g}$ wheat) ${ }^{-1} \mathrm{~min}^{-1}$. Wheat, which is a very sensitive product for Aspergillus $s p p$ and AFs formation under unsuitable processing conditions, is an important product for the economy and import of Egypt. The objective of this work was to study the effect of ozone gas on degradation of $\mathrm{AFB}_{1}$ in wheat grain and evaluate the effects of exposure to ozone gas on Aspergillus flavus strain producer of $\mathrm{AFB}_{1}$.

\section{Material and Methods}

\section{Chemicals and reagents}

Aflatoxin $\mathrm{B}_{1}$ from Aspergillus flavus was purchased from Sigma Chemical Co. (St. Luis, MO 63118, U.S.A.). The immunoaffinity column AflaTes ${ }^{\circledR}$ HPLC were obtained from VICAM (Watertown, MA, USA). Methanol, trifluoroacetic acid, and sodium chloride, were purchased from Sigma chemical Co. (St. Louis, MO, U.S.A.). All solvents were of HPLC grade. The water was double distilled with Millipore water purification system (Bedford, M A, USA). Potato dextrose agar (PDA) and Yeast extract and peptone were purchased from Sigma-Aldrich, France.

Fungal strain: Toxigenic strain of Aspergillus flavus (ATCC 28542) was purchased from MIRCEN, (Microbial Research Center, Faculty of Agriculture, Ain Shams University, Cairo, Egypt).

\section{Wheat samples}

Wheat samples were obtained from the South Cairo Mills Company, Cairo, Egypt.

\section{Method}

\section{Preparation of artificially wheat grain samples}

Five replicates of each whole wheat samples were spiked with 10 and $20 \mu \mathrm{g} / \mathrm{kg} \mathrm{AFB}$ and followed by shaking to $10-15 \mathrm{~min}$. In addition samples control with spiked without treatment $\left(\mathrm{O}_{3}\right)$ and samples control without spiked with treatment. Standard stock was prepared according to the AOAC [22] method [23].

\section{Preparation samples treatment}

Whole wheat was transferred into a $500 \mathrm{~mL}$ flask and the sample flask was plugged with a silicone stopper with 2 holes in it. One hole was for the ozone line and the other was for tubing connected to the ozone destruct unit. The wheat was treated for 5, 10, 15 and 20 min at room temperature with two different ozone concentrations (20 and 40 $\mathrm{ppm})$. Ozone gas was produced from air using ozone generator Model OZO 6 VTTL OZO Max Ltd, Shefford, Quebec Canada (http://www. ozomax.com)

\section{Preparation of potato dextrose agar (PDA) and yeast extract sucrose (YES)}

The (PDA) was prepared according to the manufacturers directions by adding $40 \mathrm{~g}$ of the dehydrated PDA to $1000 \mathrm{ml}$ of distilled water. The culture media was then mixed and autoclaved at $121^{\circ} \mathrm{C}$ for $15 \mathrm{~min}$ YES culture was carried out according to the method of Munimbazi and Bullerman [20] at following (2\% yeast extract and $15 \%$ sucrose / liter distilled water) were transferred into 500 Erlenmeyer flask, and autoclaved at $121^{\circ} \mathrm{C}$ for $15 \mathrm{~min}$.

\section{Preparation of inocula}

Preparation of spore suspensions: The fungal culture was grown on (PDA) slants at $28^{\circ} \mathrm{C}$ for about 14 days or until good sporulation was observed. Spores were harvested by adding growing the A.flavus by adding $10 \mathrm{ml}$ of sterilized aqueous solution of Tween $80(0.05 \%$ v/v) to cultures Ramakrishna et al. [24] Spore suspensions were then centrifuged at 20,000 $\mathrm{rcf}$ for $5 \mathrm{~min}$ and the Supernatants discarded. The spore concentrations were adjusted to yield a final count of $10^{5}$ spores/ $\mathrm{ml}$ and the ensuing preparations were used as spore inoculum.

\section{Effect of ozone on fungal growth from mycelia inocula}

To determine the effect of ozone on mycelia inocula of the $A$. flavus, (PDA) plates were spread with aliquots of $50 \mu \mathrm{l}$ of mycelial suspensions. After 14 days on inoculated plates were exposed to two ozone concentrations of 20 and $40 \mathrm{ppm}$ for 5, 10, 15 and $20 \mathrm{~min}$ each three replicate for concentration with time exposure. The ozone exposed plates were compared with controls which were not treated.

\section{Preparation of fungi for estimation of total biomass}

One hundred $\mathrm{ml}$ of (YES) were transferred into 500 Erlenmeyer flasks, and autoclaved at $121^{\circ} \mathrm{C}$ for $15 \mathrm{~min}$. The YES medium was inoculated with $1 \mathrm{ml}$ of wet biomass of A.flavus strain was Incubated at $28^{\circ} \mathrm{C}$ for 14 days after treated with ozone concentrations of 20 and 40 ppm for 5, 10, 15 and 20 min each three replicate for concentration with time exposure. The biomass was harvested by centrifuging the culture broth and decanting the supernatant. The wet biomass was used as the inoculum to study the effect of ozone on overall biomass production. The percent mycelia inhibition was calculated.

Inhibition zone percentage $=[($ Area of fungi dead $(\mathrm{cm}) /$ all growth area $(\mathrm{cm})] \mathrm{X} 100$.

Inhibition of production $\mathrm{AFB}_{1}$ percentage $=\mathrm{C}-\mathrm{T} / \mathrm{C}$

Where: $\mathrm{C}$ is sample control and $\mathrm{T}$ is sample treated with ozone

\section{Extraction of $\mathrm{AFB}_{1}$}

Sample extraction: Weigh $50 \mathrm{~g}$ sample with $10 \mathrm{~g}$ salt sodium chloride and place in blender jar. Add to jar $200 \mathrm{ml}$ methanol: water (80:20). Cover blender jar and blend at high speed for 1 minute. Remove cover from jar and pour extract into fluted filter paper. Collect filtrate in a clean vessel.

Extract dilution: Pipet or pour $10 \mathrm{ml}$ filtered extract into a clean vessel. Dilute extract with $40 \mathrm{~mL}$ of purified water. Mix well. Filters dilute extract through glass microfiber filter into a glass syringe barrel using markings on barrel to measure $4 \mathrm{ml}$.

Immunoaffinity chromatography: Pass $4 \mathrm{~mL}$ filtered diluted extract $(4 \mathrm{~mL}=0.2 \mathrm{~g}$ sample equivalent) completely through AflaTest ${ }^{\circledR}$-P affinity column at a rate of about 1-2 drops/second until air comes through column. Pass $5 \mathrm{~mL}$ of purified water through the column at a 
rate of about 2 drops/second. Elute affinity column by passing $1.0 \mathrm{~mL}$ HPLC grade methanol through column at a rate of 1-2 drops/second and collecting all of the sample eluate $(1 \mathrm{~mL})$ in a glass vial. Evaporated to dryness under stream of nitrogen and was determination of HPLC.

\section{Extraction of $\mathrm{AFB}_{1}$ of liquid media}

$\mathrm{AFB}_{1}$ was extracted according to the method described by El-Banna et al. [25] Extraction was carried out using $20 \mathrm{ml}$ of chloroform (twice with $10 \mathrm{ml}$ media), and homogenization for $3 \mathrm{~min}$ in a separation funnel. The chloroform phase was filtered through Whatman no. 3 filter paper and concentrated to dryness under a nitrogen steam.

\section{Determination of $\mathrm{AFB}_{1}$ by HPLC}

Derivatization: The derivatives of samples and standard were done as follow: $100 \mu \mathrm{l}$ of trifluoroacetic acid (TFA) was added to samples and mixed well for $30 \mathrm{~s}$ and the mixture stand for $15 \mathrm{~min}$. $900 \mu \mathrm{l}$ of water: acetonitrile $(9: 1 \mathrm{v} / \mathrm{v})$ were added and mixed well by vortex for $30 \mathrm{~s}$.and the mixture was used for HPLC analysis.

Apparatus: 1. The HPLC system consisted of Waters Binary Pump Model 1525, a Model Waters 1500 Rheodyne manual injector, a Watres 2475 Multi- Wavelength Fluorescence Detector, and a data workstation with software Breeze 2. A phenomenex C18 (250 x 4.6 $\mathrm{mm}$ i.d.), $5 \mu \mathrm{m}$ from Waters corporation (USA). An isocratic system with water: methanol: acetonitrile 240:120:40 [26]. The separation was performed at ambient temperature at a flow rate of $1.0 \mathrm{~mL} / \mathrm{min}$. The injection volume was $20 \mu \mathrm{L}$ for both standard solutions and sample extracts. The fluorescence detector was operated at wavelength of 360 $\mathrm{nm}$ for excision and $440 \mathrm{~nm}$ for emission.

Statistical analysis: All data were statistically analyzed using the General Linear Model of the SPSS var. 19. The significance of the differences among different methods was determined by WallerDuncan k-ratio [27]. All statements of significance were based on probability of $\mathrm{p}<0.05$.

\section{Results and Discussion}

\section{Effect of ozone gas on $\mathrm{AFB}_{1}$ in artificially contaminated wheat grain}

Data presented in Figure 1 showed content of $\mathrm{AFB}_{1}$ in wheat grain samples were artificially contaminated with 10 and $20 \mu \mathrm{g} / \mathrm{kg}$. $\mathrm{AFB}_{1}$ was degraded to $3.74 \pm 0.035$ and $1.59 \pm 0.009 \mu \mathrm{g} / \mathrm{kg}$ after 5 and $20 \mathrm{~min}$ exposure to ozone at $20 \mathrm{ppm}$ respectively. While observed increases of degraded with $40 \mathrm{ppm}$ ozone, degraded to $2.80 \pm 047$ and $1.33 \pm 0.014$ after ozonation for 5 and 20 min respectively. Wheat grains samples were artificially contaminated with $20 \mu \mathrm{g} / \mathrm{kg} \mathrm{AFB}$ degraded to $6.72 \pm$ 0.039 and $2.65 \pm 0.039 \mu \mathrm{g} / \mathrm{kg}$ after 5 and $20 \mathrm{~min}$ exposure to ozone at 20 ppm respectively. During ozonation at $40 \mathrm{ppm}$, the $\mathrm{AFB}_{1}$ was degraded to $3.77 \pm 0.014$ and $0.668 \pm 0.010$ after 5 and 20 min respectively.

Data presented in Figure 2 showed the reductions of $\mathrm{AFB}_{1}$ in artificially contaminated wheat $10 \mu \mathrm{g} / \mathrm{kg}$ after ozonation for $20 \mathrm{~min}$ at 20 and 40 ppm ozone gas were 84.1 and $86.75 \%$ respectively, While observed increase on reduction with $20 \mu \mathrm{g} / \mathrm{kg} \mathrm{AFB}$, it was 86.7 and $96.66 \%$ after ozonation for $20 \mathrm{~min}$ at 20 and $40 \mathrm{ppm}$ ozone respectively.

These results are in agreement with the available literature on AFs degradation by ozone $[11,12,16,18,19,28]$ in which the observed reductions of $\mathrm{AFB}_{1}$ contents of contaminated foods varied from $56 \%$ to $95 \%$. It is proposed that the degradation begins with attack of ozone at the $\mathrm{C}_{8-9}$ double bond with the net addition of two atoms of oxygen

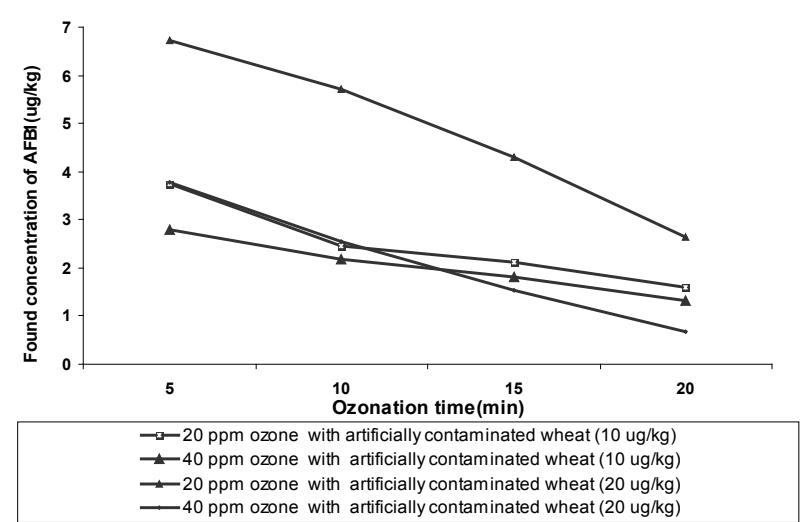

Figure 1: Effect of ozone gas on degradation of $\mathrm{AFB}_{1}$ in artificially contaminated wheat.

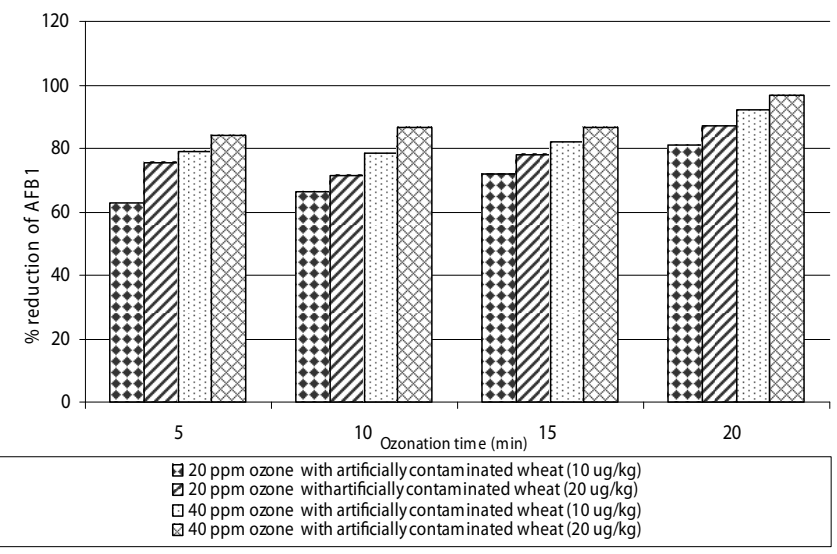

Figure 2: Effect of ozone treatment on reduction of $\mathrm{AFB}_{1}$ in artificially contaminated wheat.

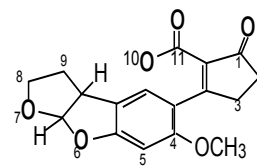

Aflatoxin B
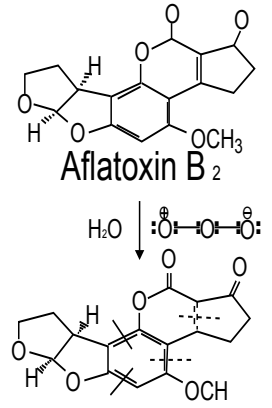

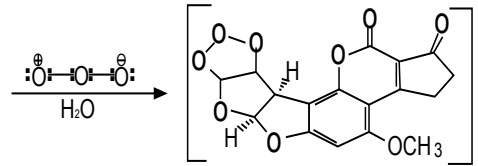

AflatoXin moloZonide
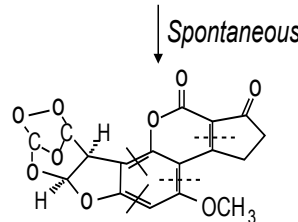

AflatoXin oZonide

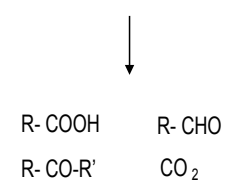

Figure 3: Mechanism for the addition of ozone to aflatoxins. (McKenzie et al.,1997). 
Figure 3. It is noted here to increase the percentage of reduction with an increased concentration. Also found to increase the percentage of reduction with increasing dose of ozone this makes sense. HPLC chromatograms for $\mathrm{AFB}_{1}(20 \mu \mathrm{g} / \mathrm{kg})$ the artificially wheat grain samples were presented in Figure 4 for exposure times (5, 10, 15 and $20 \mathrm{~min}$ ) after ozonation at $20 \mathrm{ppm}$.

The analysis of variance showed higher significant differences between the concentrations of $\mathrm{AFB}_{1}$ extracted after treated with different dose of ozone. These results clearly indicated that the exposure time higher significantly than the dose of ozone. Ozone moves through grain slowly because the gas reacts with the chemical constituents present in the outer layer of grain (seed coat). Diffusion of ozone into the grain depends upon the grain characteristics [29]. Ozone adsorption in the grain layer depends on ozone concentration in the feed gas, duration of exposure, gas flow rate, temperature, grain characteristics and the presence of other organic matter such as insects and surface microbial status of the grain. Presence of moisture also plays an important role in ozone reactivity with grain because water solubilizes ozone and increase contact between gas and grain. These results were below the limit of the Egypt Food Codex, which select the level of last $\mathrm{AFB}_{1}$ in food by $5 \mu \mathrm{g} / \mathrm{kg}$.

\section{Inhibitory effect of ozone against mycelial growth of A.flavus}

Data presented in Figure 5 showed the percentage of inhibition zone from fungal growth was 46.4 to $87.8 \%$ after ozonation at $20 \mathrm{ppm}$ from 5 to $20 \mathrm{~min}$ respectively. Ozonation at $40 \mathrm{ppm}$ the percentage of inhibition was 65.6 to $95.6 \%$ with 5 to 20 min respectively. It stated that the percentage of inhibition increases with increasing time exposure and dose of ozone used. These results are consistent with; Allen et al. [20] they found that at an ozonation rate of $0.01 \mathrm{mg} / \mathrm{g} /$ min $39 \%$ of fungal spores were inactivated after $5 \mathrm{~min}$ of treatment. As the ozone rate increased, the level of spore inactivation increased; $78 \%$ inactivation at a rate of $0.07 \mathrm{mg} / \mathrm{g} / \mathrm{min}$ and a $96 \%$ inactivation at a rate of $0.16 \mathrm{mg} / \mathrm{g} / \mathrm{min}$. Also Wu et al. [18] reported that gaseous ozone was very effective in the inactivated of fungi associated with the wheat within $5 \mathrm{~min}$ of ozonation, $96.6 \%$ of the fungal spores were inactivated by applying $0.33 \mathrm{mg}$ of ozone (g wheat) ${ }^{-1} \mathrm{~min}^{-1}$. Figure 6 appear killed zone in on PDA.

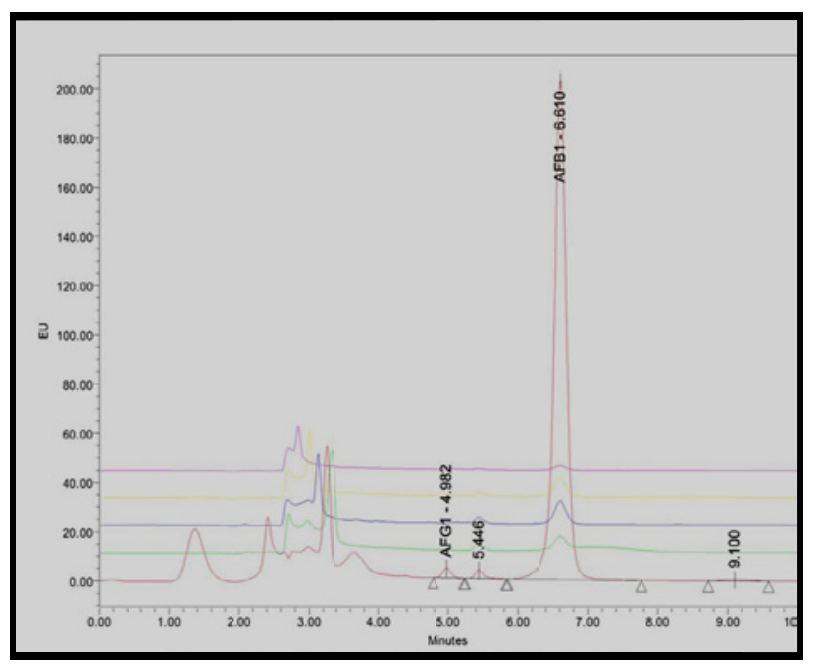

Figure 4: HPLC chromatogram of $\mathrm{AFB}_{1}$ in artificially contaminated wheat (20 $\mu \mathrm{g} / \mathrm{kg}$ ) after ozonation at $20 \mathrm{ppm}$ with different exposure time and control.

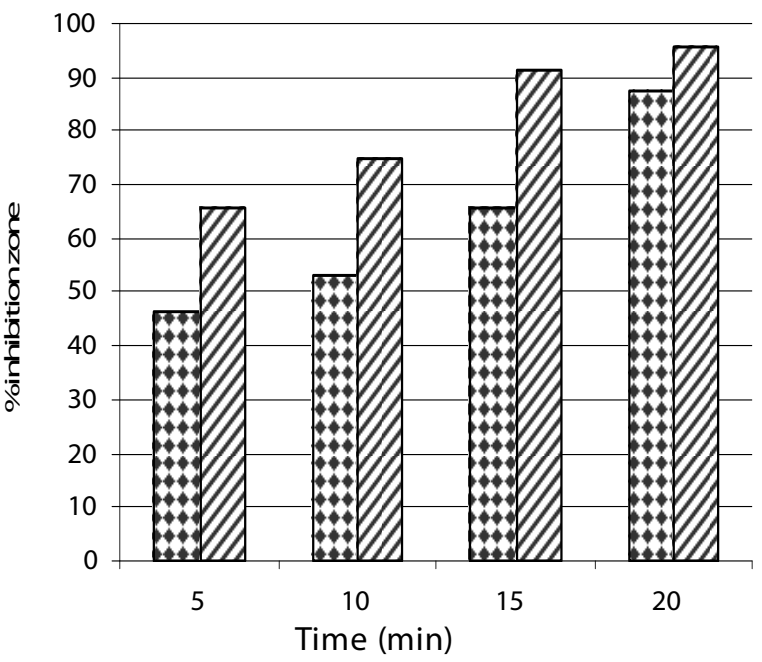

$$
\text { O O3 (20 ppm) }
$$

O3 (40 ppm)

Figure 5: percentage of inhibition zone of growth strain Aspergillus flavus.

Ozone was thought to kill microorganisms by oxidation of cellular components such as sulphydryl groups and amino acids of enzymes, peptides, proteins and polyunsaturated fatty acids, and oxidation of the cell membrane [30-33]. Sensitivity of microorganisms to ozone was affected by several factors including the method of applied ozone, strain of the microorganism, physiological state of cells, growth level, $\mathrm{pH}$ of the medium, temperature, humidity and presence of other chemicals such as acids, surfactants and sugars. In pure suspensions of bacteria, yeasts, molds, viruses and parasites, low concentrations of ozone and short contact times were sufficient to inactivation. However, the ozone concentration of water was rapidly reduced in presence of organic material in foods [34].

Returns the capacity of ozone to kill fungus and bacteria that the cell wall of the fungus is made up of several layers containing $80 \%$ carbohydrate and $10 \%$ protein and Glycoprotein also contains many cells on the wall of the bilateral ties of sulfur, which makes them subject to oxidation by ozone $[35,36]$. Also imbued with ozone gas through the cell wall into the cells and combines with cytoplasm, leading to an imbalance in the components of the cell and thus her death, and inability to perform the functions of natural and coerce the inability of this fungus to produce AFs after exposure to ozone [37,38] fungal mycelium from contaminated food may be directly responsible for spread of spoilage when stored with uncontaminated food.

Therefore, it is important to stop any growth of the fungus before storage or even to kill her. With the availability of food all the conditions of temperature and humidity in the warehouse, it is easy to produce AFs.

\section{In vitro effect of ozone gas on $\mathrm{AFB}_{1}$ production}

Data in Figure 7 show amount of $\mathrm{AFB}_{1}$ production by A.flavus after ozonation at 20 and $40 \mathrm{ppm}$ ozone gas. Concentration of $\mathrm{AFB}_{1}$ in media after $5,10,15$ and $20 \mathrm{~min}$ with $20 \mathrm{ppm}$ ozone were $109.65 \pm 0.361$, $88.19 \pm 0.150$, and $75.52 \pm 0.133$ and $73.54 \pm 0.029 \mu \mathrm{g} / 100 \mathrm{ml}$ media respectively. While after ozonation at $40 \mathrm{ppm}$ ozone gas were 83.21 $\pm 0.005,66.71 \pm 66.71$, and $47.28 \pm 0.032$ and $42.38 \pm 0.088 \mu \mathrm{g} / 100$ $\mathrm{ml}$ for $5,10,15$ and 20 min respectively but in media untreated was $185.6 \mu \mathrm{g} / 100 \mathrm{ml}$. 
Citation: El-Desouky TA, Sharoba AMA, El-Desouky Al, El-Mansy HA, Naguib K (2012) Effect of Ozone Gas on Degradation of Aflatoxin B1 and Aspergillus Flavus Fungal. J Environment Analytic Toxicol 2:128. doi:10.4172/2161-0525.1000128
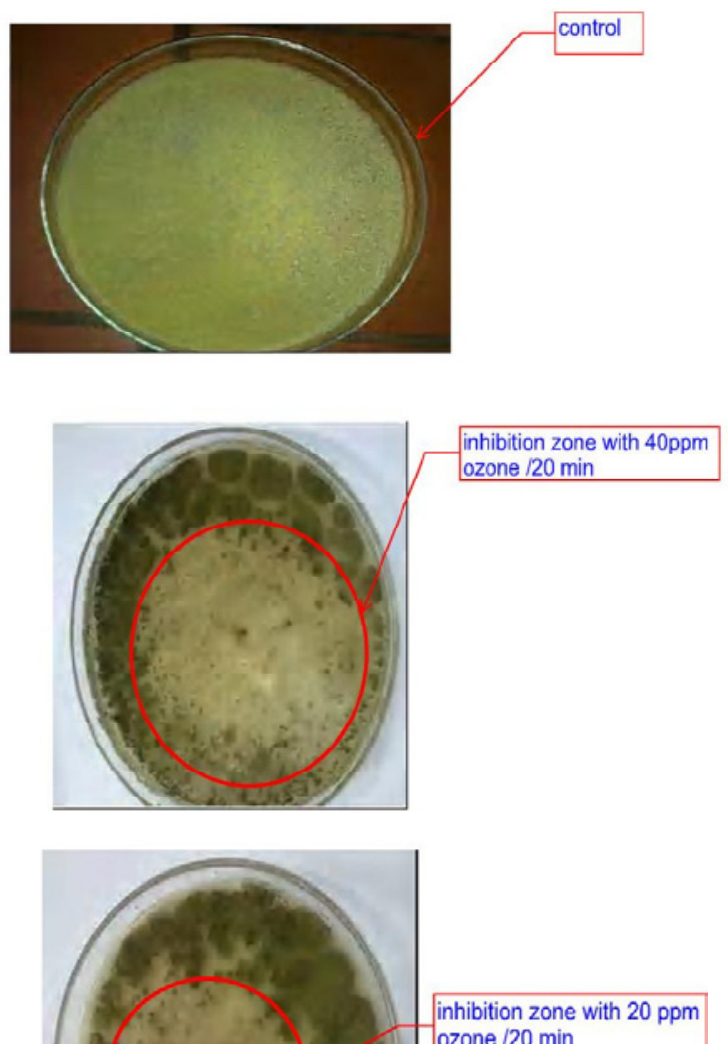

ozone /20 min
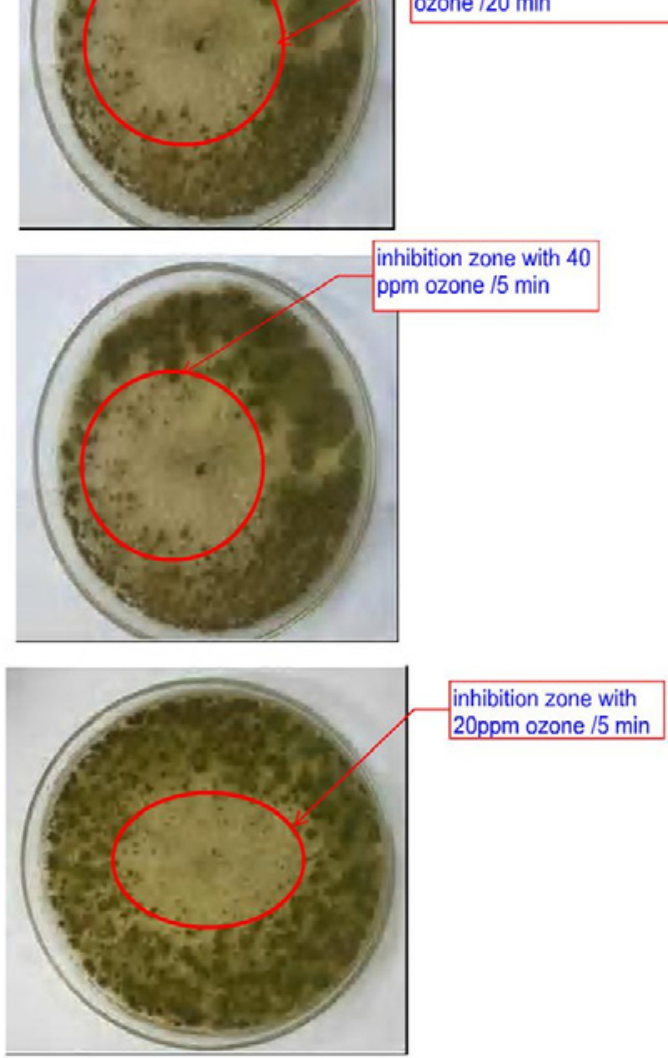

Control= Aspergillus flavus

Figure 6: Inhibition of Aspergillus flavus growth by ozone gas on PDA media.

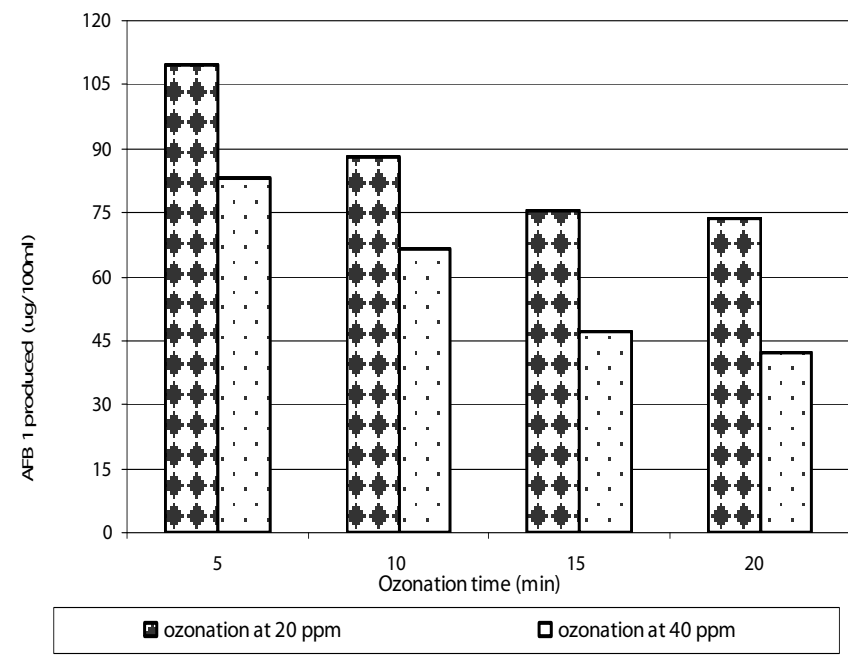

Figure 7: $\mathrm{AFB}_{1}$ production of Aspergillus flavus in YES media at various concentrations ozone gas.

The mechanism of AFs inactivation synthesized by A.flavus, colonies using ozonation process. The anthraquinone pigments produced by the fungus may be help in storage for subsequent rapid conversion to AFs under this perspective; ozonation could destroy anthraquinonic intermediates, thus preventing the making of AFs [38]

\section{Conclusion}

Ozone degraded $\mathrm{AFB}_{1}$ in wheat grains, and generally there was significant variation between ozonation time on reduction of $\mathrm{AFB}$ and all one concentration of used ozone. Consequently, the treatment with ozone at $40 \mathrm{ppm}$ for $20 \mathrm{~min}$ could be an effective method for the degradation of $\mathrm{AFB}_{1}$ in wheat grain.

\section{References}

1. Coulombe RA (1991) Aflatoxins. P.103-143. In RP Sharma, DK Salunkhe (ed.) Mycotoxins and Phytoalexins. Boca Raton FL, CRC Press.

2. Eaton DL, Groopman JD (1994) The Toxicology of Aflatoxins: Human Health Veterinary and Agricultural Significance. Academic Press, San Diego, CA

3. Cardwell KFD, Desjardins SH (2004) The Cost of Achieving Food Security and Food Quality.

4. Jolly CM, Bayard B, Awuah RT, Fialor SC, Williams JT (2009) Examining the Structure of Awareness and Perceptions of Groundnut Aflatoxin among Ghanaian Health and Agricultural Professionals and its influence on their Actions. J Socio-Econ 38: 280-287.

5. Coulibaly O, Hell K, Bandyopadhyay R, Hounkponou S, Leslie JF (2008) Mycotoxins: Detection Methods, Management. CAB International Public Health and Agricultural Trade.

6. Ominski KH, Frohlich AA, Marquardt RR, Crow GH, Abramson D (1996) The incidence and distribution of ochratoxin $\mathrm{A}$ in western Canadian swine. Food Addit Contam 13: 185-198.

7. Frisvad JC (1995) Mycotoxins and mycotoxigenic fungi in storage. In: Jayas D, White NDG, Muir WE (Eds.), Stored-Grain Ecosystems. Marcel Dekker, New York, NY 251-288.

8. Abramson D, Hulasare R, White NDG, Jayas DS, Marquardt RR (1999) Mycotoxin formation in hulless barley during granary storage at 15 and $19 \%$ moisture content. J Stored Prod Res 35: 297-305

9. Karlovsky P (1999) Biological detoxification of fungal toxins and its use in plan breeding, feed and food production. Nat Toxins 7: 1-23.

10. Trigo - Stockli DM (2002) Effect of processing on deoxynivalenol and othe trichotecenes. Adv Exp Med Biol 504: 181-188. 
Citation: El-Desouky TA, Sharoba AMA, El-Desouky Al, El-Mansy HA, Naguib K (2012) Effect of Ozone Gas on Degradation of Aflatoxin B1 and Aspergillus Flavus Fungal. J Environment Analytic Toxicol 2:128. doi:10.4172/2161-0525.1000128

11. Samarajeewa U, AC Sen, MD Cohen, CI Wei (1990) Detoxification of aflatoxins in foods and feeds by physical and chemical methods. J Food Prot 53: 489-501.

12. McKenzie KS, Kubena LF, Denvir AJ, Rogers TD, Hitchens GD, et al. (1998) Aflatoxicosis in turkey poults is prevented by treatment of naturally contaminated corn with ozone generated by electrolysis. Poult Sci 77: 1094-1102.

13. Shunmugam G, Jayas DS, White NDG, Muir WE (2005) Diffusion of carbon dioxide through grain bulks. J Stored Prod Res 41: 131-144.

14. Lemke SL, Mayura K, Ottinger SE, McKenzie KS, Wang N, et al. (1999) Assessment of the estrogenic effects of zearalenone after treatment with ozone utilizing the mouse uterine weight bioassay. J Toxicol Environ Health A 56: 283-295.

15. Pala M (2001) Ozone and ozone treatment in the fruit juice industry. Gida Teknolojisi 5: 59-65.

16. Proctor AD, Ahmedna M, Kumar JV, Goktepe I (2004) Degradation of aflatoxins in peanut kernels/flour by gaseous ozonation and mild heat treatment. Food Add Cont 21: 786-793.

17. Kells AA, Mason LJ, Maier DE, Wolushuk CP (2001) Efficacy and fumigation characteristics of ozone in stored maize. J Stored Prod Res 37: 371-382.

18. Maeba H, Takamoto $Y$, Kamimura M, Miura T (1988) Destruction and detoxification of aflatoxins with ozone. J Food Sci 53: 667-668.

19. Inan F, Pala M, Doymaz I (2007) Use of ozone in detoxification of aflatoxin B in red pepper. J Stored Prod Res 43:425-429.

20. Allen B, Wu JN, Doan H (2003) Inactivation of fungi associated with barley grain by gaseous ozone. J Environ Sci Health B 38: 617-630.

21. Wu JN, Doan H, Cuenca MA (2006) Investigation of gaseous ozone as an antifungal fumigant for stored wheat. J Chem Technol Biotechol 81: 1288-1293.

22. AOAC (2000) Association of official analytical chemists. Official methods of analysis 17 th. Washington, DC.

23. Munimbazi C, Bullerman LB (1998) Isolation and partial characterization of antifungal metabolites of Bacillus pumilus. J Appl Microbiol 84: 959-968.

24. RamakrishnaN. Lacey J, Smith JE (1996) Aspergillus flavus colonization and aflatoxin $B_{1}$ formation in barley grain during interaction with other fungi. Mycopathologia 136: 53-63.
25. El-Banna AA, Pitt J I, Leistner L (1987 Production of mycotoxins by Penicillium species. Syst Appl Microbiol 10: 42-46.

26. Deabes MM, Aboelsoud NH, Abou El-Kassem TL (2011) In vitro Inhibition of growth and aflatoxin B, production of Aspergillus flavus strain (ATCC 16872) by various medicinal plant essential oils. Macedonian Journal of Medical Sciences 4: 345-350

27. Waller RA, Duncan DB (1969) A Bayes rule for the symmetric multiple comparison problems. J American Statistical Assoc 64: 1484-1503.

28. Prudente AD, King JM (2002) Efficacy and safety evaluation of ozone to degrade aflatoxin in corn. J Food Sci 67: 2866-2872.

29. Tiwari BK, Brennan CS, Curran T, Gallagher E, Cullen PJ, et al. (2010) Application of ozone in grain processing. J Cereal Sci 51: 248-255.

30. Victorin K (1992) Review of genotoxicity of ozone. Mutat Res 227: 221-238.

31. Xu L (1999) Use of ozone to improve the safety of fresh fruits and vegetables. Food Technol 53: 58-63.

32. Young SB, Setlow $P$ (2004) Mechanism of Bacillus subtilis spore resistance to and killing by aqueous ozone. J Appl Microbiol 96: 1133-1142.

33. Das E, Candan Gürakan G, Bayindirli A (2006) Effect of controlled atmosphere storage, modified atmosphere packaging and gaseous ozone treatment on the survival of Salmonella enteritidis on cherry tomatoes. Food Microbiol 23 430-438.

34. Sharma RR, Demirci A, Beuchat LR, Fett WF (2002) In activation of Escherichia coli $\mathrm{O} 157: \mathrm{H} 7$ on inoculated alfalfa seeds with ozonated water and heat treatment. J Food Prot 65: 447-451.

35. Escriche I, Serra JA, Gomez M, Galotto MJ (2001) Effect of ozone treatment and storage temperature on physicochemical properties of mushrooms (Agaris bisporus). Food Sci Technol Int 7: 251-258

36. Karaca H, Velioglu YS (2007) Ozone applications in fruit and vegetable processing. Food Reviews International 23: 91-106.

37. Barth MM, Zhou CEN, Mercier J, Payne FA (1995) Ozone storage effects on anthocyanin content and fungal growth in blackberries. J Food Sci 60: 12861288.

38. Zotti M, Porro R, Vizzini A, Mariotti MG (2008) Inactivation of Aspergillus spp. by Ozone Treatment. Ozone: Science \& Engineering 30: 423-430 